\title{
THE EFFECTS R\&D EXPENDITURES ON THE MARKET VALUE IN THE TELECOMMUNICATION INDUSTRY- EVIDENCE FROM NORTH AMERICA.
}

\author{
By Nguyen Van Phuong ${ }^{1}$
}

Thelinkagebetween $R \& D$ spending and market value of firms has been continuously debated from time to time. Many studies have proved that there is a positive impact. Meanwhile, other studies have proved that it depends on which sectors in the economy, some sectors have a strongly positive effect but the others have a weak effect. This paper estimates the relationship between $R \& D$ expenditures and market price in the telecommunication sector. First, by using the COMPUSTAT annual industrials of North America in period 1950-2005, we find a strong evidence of the positive relationship. Second, we implement another test to investigate some particular characteristics of the telecommunication sector during the process of liberalization telecommunication markets as well as the emerging internet and developing Information Technology era. Overall, our result is consistent with some previous studies. Third, we expand the model and find that price per share is positively associated with other variables including total assets per share and earning per share.

\section{Introduction}

The Research and Development (R\&D) investment is playing a very important role in sustaining and achieving firms' business goals. The effects of $R \& D$ expenditures have been attracted more attention under many different aspects. There are many different approaches to study the role of R\&D associated with firms' innovations and development. Overall, some scholars focus on studying the effective internal as well as external role of R\&D investment in the whole economy. Meanwhile, the others concentrate on analyzing the effects of $R \& D$ expenditure in a particular industry, in manufacturing and non-manufacturing firms as well as the whole industrials. In the internal role of $R \& D$, scholars often study the influences of $R \& D$ investment on the firms' innovations and patents. Some authors following this trend are Levin at el Griliches (1987) and Acs and Audretsch (1998). In the external aspect of R\&D, many authors focus on studying $R \& D$ operations as a very important strategy for firms to be sustainable and achievable business objectives under the pressure of the globally competitive environment. In addition, the external aspect has been rapidly expanded and debated the phenomenon of outsourcing R\&D expenditures. For instance, Henderson and Cockburn (1994) provide evidence to explain an essential fraction of the variance in research productivity across firms; Quinn (2000) shows advantages of outsourcing innovation such as resource limits, specialist talents, attracting talent and faster arrival than in-house.

In this paper, we estimate the relationship between R\&D expenditures and market price in the telecommunication sector. The linkage between $R \& D$ spending and market value of firms has been continuously debated from time to time. Many studies have proved that there is a positive impact. However, other studies have also proved that it depends on which sectors in the economy, some sectors have a strongly positive effect but the others have a weak effect. For instance, Kothari et al (2002) throughout empirical study using financial data from 1972-1997 for a large sample firm provides evidence that the future benefits of $R \& D$ expenditures are uncertainty than those of investments in capital expenditure. Ho et al (2005) shows

\footnotetext{
${ }^{1}$ Post \& Telecommunications Institute and Technology at Ho Chi Minh City
} 
that the intensive investment in $R \& D$ contributes positively to the one-year stock market performances of manufacturing firms but not for non-manufacturing firms. As our knowledge, most of previous studies have concentrated on studying this linkage in the whole industrials or manufacturing and non-manufacturing firms or some particular sectors such as the pharmaceutical and agricultural industry and so forth. The prior researches of this linkage in the telecommunication sector are limited resource. Therefore, the purpose of this paper is to add to the literature on the effects of $\mathrm{R} \& \mathrm{D}$ expenditures on market value in a particular industry, the telecommunication sector.

By using the COMPUSTAT annual industrials of North America the in period 1950-2005, we select the telecommunication firms to test the relationship between market value of firms in the telecommunication industry and R\&D expenditures. As a result, we find a strong evidence of the positive relationship. Second, we implement another test by using usable observations of the data for each firm and each year in period 1971-2005, the results have reflected some particular characteristics of the telecommunication sector during the process of liberalization telecommunication markets as well as the emerging internet and developing Information Technology (IT) era. Overall, our result is consistent with the previous studies. For instance, our result of R\&D per share achieves the peak in 1993, that is consistent with the result of Ogden et al (2002, page 307). Third, we expand the model by adding two independent variables including total assets per share and earning per share to estimate the relationship between price per share (PPS) with three independent variables. As our expectation, all of the estimated coefficients are positive and statistically significant.

The rest of this paper is organized as follows. In Section 2, we review prior studies about the role of $R \& D$ expenditures in sustaining and developing business, while Section 3 presents empirical tests. Finally, Section 4 gives some concluding remarks.

\section{Literature Review}

The role of internal R\&D has been studied by many authors. One of pioneers studying this trend is Griliches at el (1979 and 1987), the authors focus on studying the role of internal R\&D in company innovation and show that the total number of innovations is closely related to R\&D expenditures. Acs and Audretsch (1988) develop this trend and show that the total of innovations is negatively associated with concentration and unionization, and closely associated with R\&D investment, skilled labor and the degree to which large enterprises comprise the industry. Increasingly, many scholars recognized that external $\mathrm{R} \& \mathrm{D}$ expenditures also contribute an essential role in firm innovation rates and enhancing firm's competitive ability. Cohen and Levinthal (1990) study R\&D contributing to a firm's absorptive capacity and innovative activities including basic research, the diffusion and adoption of innovations and decisions to take part in cooperative $R \& D$ ventures as external factors. This trend is followed by many other scholars. For instance, Henderson and Cockburn (1994) study the significant role of heterogeneous organizational 'competence' in competition in the context of pharmaceutical research and show that together two forms of competence (including component and architectural competence) provide evidence to explain an essential fraction of the variance in research productivity across firms. In general, in the external aspect of R\&D, many authors consider analyzing the role of $R \& D$ investment as a very important strategy for firms to be sustainable and achievable business objectives under the pressure of the globally competitive environment.

Now, we review prior studies of the role of $\mathrm{R} \& \mathrm{D}$ expenditures in improving firms' financial status. Kothari et al 
(2002) throughout empirical study using financial data from 1972-1997 for a large sample firms provides evidence that the future benefits of $R \& D$ expenditures are uncertainty than those of investments in capital expenditure. Moreover, the effects of increasing in R\&D expenditures on the return and market value as well as the risky level of $R \& D$ operations have attracted more attention. For instance, Chan et al (1999) address the historical stock return of firms doing $R \& D$ on average matches the returns on firms with no R\&D. On the other hand, they also find that R\&D intensity is positively relative to return volatility, after controlling for firm size, age and industry effects. By using a sample of around 1200 companies' expenditures on R\&D, Lev and Sougiannis (1999) provide some evidences (1) low market-to-book companies have a large R\&D capital and vice versa; (2) the ratio of $R \& D$ capital to market value is closely relative to the book-to-market ratio; (3) the return premium is essentially higher for risky $\mathrm{R} \& \mathrm{D}$ (basic research) than for lower risk $\mathrm{R} \& \mathrm{D}$ (development).

Throughout the empirical study, Sougiannis et al (2001) show that the market is apparently too pessimistic about beatendown R\&D intensive technology stocks' prospects. Firms with high R\&D to equity market value earn large excess returns. Furthermore, Amir et al (2005) also consider the effective $R \& D$ expenditures on the future earnings. They build a model to estimate the association between $R \& D$ investment and capital expenditures (CAPEX) and the variance of future earnings per share and operating income. They provide evidence that R\&D investment lead to higher volatility of future earnings than capital expenditures only in $R \& D$-intensive industries, where industry $R \& D$ intensity is measured as the $R \& D$-to-CAPEX ratio. Besides, they also show that the stronger association of $R \& D$ with uncertainty in future earnings is a recent phenomenon.
The effects of $R \& D$ investment on under-pricing of initial public offerings (IPOs) have been recently explored. Guo et al (2006) perform empirical study on a sample of 2,696 US IPOs issued during the period 1980-1995, they find that given the pervasiveness and constant growth of firms' $R \& D$ activities in modern economies, $R \& D$ expenditures play a major factor affecting IPO's performance and contribute the understanding of this important economic and capital market phenomenon. However, these effects of R\&D investment could vary between non-manufacturing firms and manufacturing firms. By empirical study of a 40 year period 1962-2001, Ho et al (2005) show that intensive investment in $R \& D$ contributes positively to the one-year stock market performances of manufacturing firms but not for non-manufacturing firms.

In recent research, Sakakibara et al (2006) have found that R\&D expenditures contribute to operating income for five years on average for firms listed in Tokyo stock exchange. Moreover, they also find R\&D capital information is reflected in stock prices throughout analyzing relationship between R\&D capital and subsequent stock return of manufacturing enterprises.

\section{Empirical Studies}

Overall, the effects of R\&D expenditures have been carefully studied by many scholars in theoretical aspects as well as empirical studies. However, most previous studies focus on the whole economy or some particular sectors such as pharmaceutical industry, non-manufacturing and manufacturing firms. In recent time, many authors have concentrated on exploring the hot muddles of outsourcing R\&D. Here, we focus on analyzing the linkage between R\&D expenditures and market value of firms in the telecommunication industry.

\section{$A$ brief background of telecommunication industry}

Telecommunications is playing a very important not only in its own right, but 
also in building a significantly backbone infrastructure to support other industries to develop. As a result, many governments usually consider investing and protecting their own telecommunication industry as a monopolistic sector. However, the effect of Telecommunication Act 1996 in USA has led to increasing competition and declining in regulations, therebyencouraginginnovations and increasing in R\&D investment, enhancing many services with lower prices. As a result of the Act is not only significant for American customers, but also leads to other countries to pursue such as France, Germany, Japan and UK and so on. The most important result is that the liberalization of telecommunication markets has moved to the world stage under auspices the World Trade Organization (WTO) (Jerram at el, 1997-1998, chapter 4: Liberalisation: Case studies in telecommunication).

Because of a particular telecommunication sector, it has encouraged us to study the linkage between the firm's market value and R\&D expenditures in this sector throughout a very simple model. In other words, we consider the following regression of the contemporaneous prices of a sample of firms at date $t$ against their respective R\&D expenditures per share $\left(R \& D_{p s}\right)$.

$$
(P P S)_{i t}=b_{i t}+a_{i t}\left(R \& D_{p s}\right)_{i t .}
$$

Our hypothesis is that firms with higher $R \& D_{p s}$ should have higher PPS, so we expect the slope coefficient $\left(a_{i t}\right)$ to be positive.

We are using the database constructed from consecutive COMPUSAT in the period 1971-2005 for S\&P industrial annual. After performing the filtering process, we are only able to identify 287 telecommunication firms with 2261 observations from the R\&D Master file used to run the regression model.

First, we pool all usable observations of the database to estimate regression Equation (1). Results of a regression of PPS against $R \& D_{p s}$ for $S \& P$ annual telecommunication firms in period 19712005 are presented as follows:

$$
\text { PPS }=12.334+5.421 \mathrm{R}_{\mathrm{ps}}
$$

The estimated value of the slope coefficient, $\mathrm{a}_{\mathrm{it}}=5.421$, is positive and statistically significant at the $1 \%$ level. These results support our hypothesis and expectation. We can see more details of regression result in Table 1.

\begin{tabular}{|c|c|c|c|c|c|c|}
\hline \multicolumn{7}{|c|}{ Analysis of Variance (Year 1971-2005) } \\
\hline & Source & DF & $\begin{array}{r}\text { Sum of } \\
\text { Squares }\end{array}$ & $\begin{array}{r}\text { Mean } \\
\text { Square }\end{array}$ & F Value & $\operatorname{Pr}>$ \\
\hline \multicolumn{7}{|l|}{$\mathrm{F}$} \\
\hline & Model & 1 & 44148 & 44148 & 117.87 & \\
\hline \multicolumn{7}{|l|}{$<.0001$} \\
\hline & Error & 2259 & 846074 & 374.53484 & & \\
\hline & Corrected Total & 2260 & 890222 & & & \\
\hline & Number of Obs & ons Used & & 2261 & & \\
\hline \multicolumn{7}{|c|}{ Parameter Estimates } \\
\hline Variance & & Parameter & Standard & & & \\
\hline $\begin{array}{l}\text { Variable } \\
\text { Inflation }\end{array}$ & DF & Estimate & Error & $\mathrm{t}$ Value & $\operatorname{Pr}>|t|$ & \\
\hline $\begin{array}{l}\text { Intercept } \\
0\end{array}$ & 1 & 12.33408 & 0.51425 & 23.98 & $<.0001$ & \\
\hline $\begin{array}{l}\text { RD_per_Share } \\
1.00000\end{array}$ & 1 & 5.42123 & 0.49933 & 10.86 & $<.0001$ & \\
\hline
\end{tabular}

Table 1 Price per share (PPS) against $R \& D_{p s}$ 
Now, we consider the linkage of price per share and $R \& D$ expenditures per share of 287 telecommunication firms in the S\&P annual industrials from 19712005 conducted from COMPUSTAT. We estimate the R\&D expenditures per share of each firm and each year against its respective price per share. In other words, we estimate the $\mathrm{Eq}(1)$ by using data on 287 telecommunication firms in the S\&P industrial annually for 1971 to 2005 and retain the estimated slope coefficient, $\mathrm{a}_{1 \mathrm{t}}$, for each year. This coefficient can be explained as the average market value of $\$ 1$ of $R \& D$ expenditures per share. These estimated coefficients are illustrated in Figure 1.

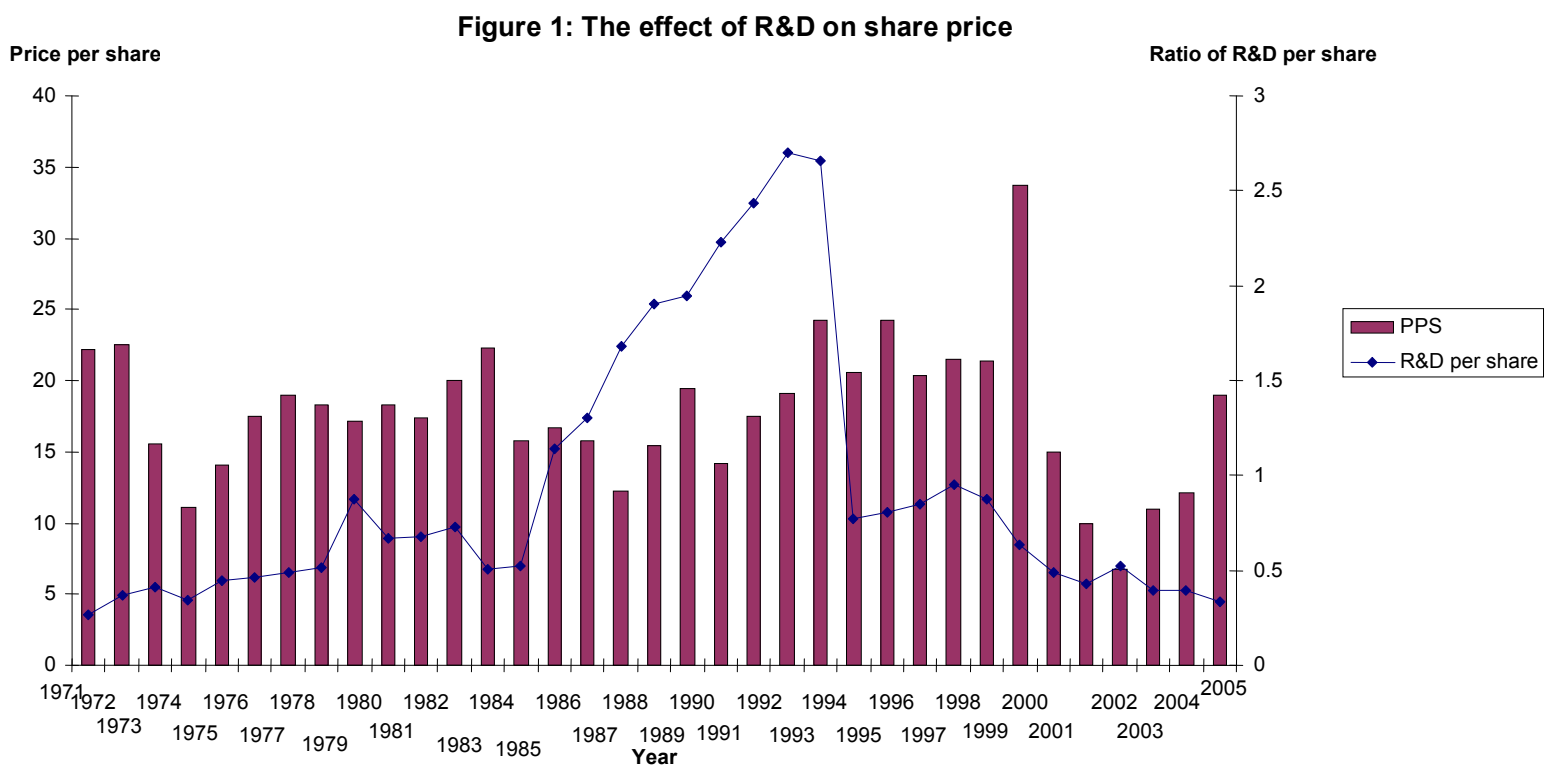

In general, we can easily see from Figure 1 that $R \& D$ expenditures per share in the telecommunication sector fluctuated and sharply increased during the period 19851994. One of many reasons able to interpret this phenomenon is that this period rapidly emerged internet and the transmission control protocol (TCP)/internet protocol (IP) wide area network. The opening of the network to commercial interests was implemented in 1985. The TCP/IP became increasingly popular in 1990s. Moreover, most of telecommunication providers also focused on upgrading the network and increasing in R\&D expenditures to catch up the cutting edge of technological advantages. However, this ratio strongly declined in 1995 and then slowly reduced following years. One of the main reasons for explaining the sharp reduction is due to the effective of an antitrust decree in 1994, as a result of the break-up AT\&T from its local telephone monopolies and this change led to the way on liberalization of telecommunication market. Furthermore, the effective telecommunication Act in 1996 also affected on declining this ratio. Overall, after 1996 the R\&D investments in telecommunication firms have been diversified and spread in many competitive firms, instead of concentration on monopolistic firms as before. This could be one of main causes leading to the deterioration. In addition, the influence of the general condition of the US stock market bubble which imploded in 2001 is the other major factor leading to declining $\mathrm{R} \& \mathrm{D}$ expenditures per share in the late 1990s and following years. In other words, this reduction is as a result of the economy facing up the following stage of underinvestment. The reduction of $\mathrm{RD}$ investment is also due to the result of the internet bubble period 1996-2000. Generally speaking, our results consistent with prior empirical research, for example, the $R \& D_{p s}$ in the telecommunication sector achieved the peak at $\$ 2.7$ in 1993. Similarly, the $\mathrm{R} \& \mathrm{D}_{\mathrm{ps}}$ for the $\mathrm{S} \& \mathrm{P}$ industrials also achieved the peak at around \$4.6 in 1993 and then it tardily decline (see Figure 2). The fluctuation 
of R\&D expenditures of telecommunication firms has closely associated with the R\&D expenditures of the whole economy. This once more provides a strong evidence to prove that the telecommunication sector has been playing a very important role in supporting other industrials to develop and contributing a significant proportion in the whole economy.

Second, we can easily recognize that PPS could be influenced by other factors behind R\&D expenditures such as total assets per share $\left(\mathrm{TA}_{\mathrm{ps}}\right)$ and earning per share (EPS). Our hypothesis is that the telecommunication firms with the higher $\mathrm{TA}_{\mathrm{ps}}$, higher EPS or higher R\&D expenditure per share should have the higher PPS. Therefore, Eq.(1) is modified by adding two additional independent variables including $\mathrm{TA}_{\mathrm{ps}}$ and EPS.

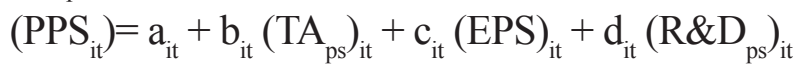

To test the new regression model, we alsouse the COMPUSTAT annualindustrials. However, we extend the time series period from 1950 to 2005, instead of period 1971-
2005. The number of telecommunication firms in our sample is the same as before (287 firms) but the number of observations is increased from 2261 to 2312 . The data process is the same as the above description of the first model. After pooling all of observations, we run the regression model and get the following result:

$$
\left(\mathrm{PPS}_{\mathrm{it}}\right)=7.774+0.369\left(\mathrm{TA}_{\mathrm{ps}}\right)+2.261(\mathrm{EPS})+
$$

$$
2.814\left(\mathrm{R} \& \mathrm{D}_{\mathrm{ps}}\right)
$$

As our expectation, all of the coefficients are positive and statistically significant at $1 \%$ level. Besides, the adjusted $\mathrm{R}^{2}$ is 42.53 percent much larger than that of the first model. We can see more details of the regression results in Table 2.

Now, we consider the estimated coefficients in Eq.(4), we easily see that the coefficient of $R \& D_{\text {s }}$ is the largest one (2.814). It means that $\mathrm{R} \& \mathrm{D}$ expenditures contribute an essential portion in determining PPS. The second largest one is the coefficient of earning per share (2.261) and the smallest one is the coefficient of total assets per share (0.369).

Table 2

\begin{tabular}{|c|c|c|c|c|c|c|}
\hline \multicolumn{7}{|c|}{ Analysis of Variance (Year 1950-2005) } \\
\hline & Source & $\mathrm{DF}$ & $\begin{array}{l}\text { Sum of } \\
\text { Squares }\end{array}$ & $\begin{array}{r}\text { Mean } \\
\text { Square }\end{array}$ & F Value & $\operatorname{Pr}>$ \\
\hline \multicolumn{7}{|l|}{$\mathrm{F}$} \\
\hline & Model & 3 & 505033 & 168344 & 571.03 & \\
\hline \multicolumn{7}{|l|}{$<.0001$} \\
\hline & Error & 2308 & 680421 & 294.80995 & & \\
\hline & Corrected Total & 2311 & 1185455 & & & \\
\hline & Number of Obsc & Used 2312 & & & Total firms 287 & \\
\hline \multicolumn{7}{|c|}{ Parameter Estimates } \\
\hline Variance & & Parameter & Standard & & & \\
\hline $\begin{array}{l}\text { Variable } \\
\text { Inflation }\end{array}$ & DF & Estimate & Error & t Value & $\operatorname{Pr}>|t|$ & \\
\hline $\begin{array}{l}\text { Intercept } \\
0\end{array}$ & 1 & 7.77401 & 0.48213 & 16.12 & $<.0001$ & \\
\hline $\begin{array}{l}\text { TA per_share } \\
1.34727\end{array}$ & 1 & 0.36931 & 0.01384 & 26.68 & $<.0001$ & \\
\hline $\begin{array}{l}\text { EPS } \\
1.31875\end{array}$ & 1 & 2.26103 & 0.17784 & 12.71 & $<.0001$ & \\
\hline $\begin{array}{l}\text { RD_per_Share } \\
1.03151\end{array}$ & 1 & 2.81486 & 0.42548 & 6.62 & $<.0001$ & \\
\hline
\end{tabular}

Regression of Price per share (PPS) against (TA $\left.{ }_{p s}\right),\left(\right.$ EPS) and $\left(R \& D_{p s}\right)$ 


\section{Conclusion}

The role of R\&D expenditures contributing to sustain and develop firms' business objectives has been explored in many various aspects. Our major findings include: first, R\&D expenditures per share are closely positive related to price per share in the telecommunication firms. This is also consistent with some previous studies such as Ogden at el (2002). Second, the estimated average of R\&D expenditures per share for each year reflects some major characteristics of the telecommunication sector during the process of liberalization of telecommunication market as well as the period of emerging IT and developing internet era and internet bubble period. Finally, we expand our basic model to test two additional independent variables including total assets per share and earning per share effect on price per share. As a result, we find that all of coefficients are positive associated with price per share as our expectation. In addition, the result once more affirms the significant role of $R \& D$ expenditures in the firms' market value, especially in the telecommunication sector.

\section{References}

Baruch Lev and Theodore Sougiannis (1999), "Penetrating the Book-toMarket Black Box: the R\&D Effect", Journal of Business Finance and Accounting, April/May 1999.

Wesley M. Cohen, Daniel A. Levinthal, 1990, Absorptive Capacity: A New Perspective on Learning and Innovation, Vol. 35, No. 1, 128-152.

Eli Amir, Yanling Guan and Gilad Livne (2005), "The Association between the Uncertainty of Future Economic Benefits and Current R\&D and Capital Expenditures: Industry and Intertemporal Analyses", the seminar at Cardiff University.

Henderson, R., and I. M. Cockburn. 1994. "Measuring Competence? Exploring Firm Effects in Pharmaceutical
Research." Strategic Management Journal 15: 63-84.

Joseph P. Ogden, Frank C. Jen and Philip F. O'Connor (2002), "Advanced Corporate Finance", Prentice Hall, 2002.

Louis K. C. Chan, Josef Lakonishok, and Theodore Sougiannis (2001), "The Stock Market Valuation of Research and Development Expenditures", the Journal of finance, Dec/2001.

Louis K.C. Chan, Josef Lakonishok, Theodore Sougiannis (1999), "The Stock Market Valuation of Research and Development Expenditures", Working Paper 7223, NBER, July 1999.

Re-Jin Guo, Baruch Lev and Charles Shi (2006), "Explaining the Short- and Long-Term IPO Anomalies in the US by R\&D”, Journal of Business Finance \& Accounting, 33(3) \& (4), 550-579, April/May 2006.

S. P. Kothari, Ted E. Laguerre, Andrew J. Leone and William E. Simon (2002), "Capitalization versus Expensing: Evidence on the Uncertainty of Future Earnings from Capital Expenditures versus R\&D Outlays", Review of Accounting Studies, 7, 355-382, 2002.

Shigeki Sakakibara, Tadanori Yosano, Euichul Jung and Hideo Kozumi (2006), "Value Relevance of R\&D Capital Information: Evidence from Tokyo Stock Exchange", Discussion Paper Series, 2006.

Quinn, B.J. 2000. Outsourcing Innovation: The New Engine of Growth. Sloan Management Review 41(14):13-23.

Yew Kee Ho, Hean Tat Keh, and Jin Mei Ong (2005), "The Effects of R\&D and Advertising on Firm Value: An Examination of Manufacturing and Nonmanufacturing Firms", IEEE, Vol. 52, No.1, Feb/2005. 